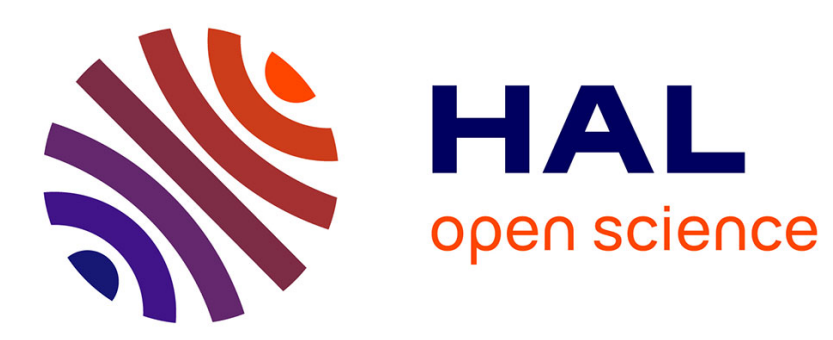

\title{
Potential value and method of producing haploids in the apple tree, malus pumila (Mill.)
}

Yves Lespinasse, Marie Godicheau, Michel Duron

\section{To cite this version:}

Yves Lespinasse, Marie Godicheau, Michel Duron. Potential value and method of producing haploids in the apple tree, malus pumila (Mill.). Acta Horticulturae, 1983, 131, pp.223-230. hal-02716874

\section{HAL Id: hal-02716874 \\ https://hal.inrae.fr/hal-02716874}

Submitted on 1 Jun 2020

HAL is a multi-disciplinary open access archive for the deposit and dissemination of scientific research documents, whether they are published or not. The documents may come from teaching and research institutions in France or abroad, or from public or private research centers.
L'archive ouverte pluridisciplinaire $\mathbf{H A L}$, est destinée au dépôt et à la diffusion de documents scientifiques de niveau recherche, publiés ou non, émanant des établissements d'enseignement et de recherche français ou étrangers, des laboratoires publics ou privés. 
POTENTIAL VALUE AND METHOD OF PRODUCING HAPLOIDS

IN THE APPLE TREE, MALUS PUMILA (Mill.)

Y. Lespinasse, Marie Godicheau, M. Duron

Institut National de la Recherche Agronomique

Station d'Arboriculture Fruitière

Beaucouzé, 49000 ANGERS

France

\begin{abstract}
Haploids are excellent experimental material for cytological and genetic studies. The basic chromosome number $(x)$ of apple is 17 . Several authors have tried to explain the origin of this number. In haploids, observations on meiotic chromosome behaviour and pairing affinities, if any, will be important as a measure of the level of chromosome duplication within the genus and thus, will be of value in understanding the origin of the Pomoideae. Moreover, it may be possible in a haploid to make a draft karyotype of the apple chromosomes.
\end{abstract}

Mutagenesis is a very suitable method to improve a species such as apple, which is propagated vegetatively. Many mutants have been selected following irradiation with gamma rays. Obviously, irradiation of haploid plants would enlarge the range of mutants.

After doubling the number of chromosomes, the plants obtained will be the first completely homozygous apple clones. Producing totally homozygous clones is only feasible by using the haploid method. Homozygous apple clones should be valuable tools for the breeder, serving as parents which can transmit desirable genes to each gamete.

The method of producing apple haploids involve the use of a genetic marking system, an hybrid derived from Malus p. niedzwetzkyana. This hybrid is homozygous for a dominant marker gene, $\mathrm{R}$, which determines the purple colour of leaves, stem and fruit. The green phenotype seedlings, presumably of a maternal origin, were selected and the chromosomes were counted. At present, 5 apple haploids have been selected from different varieties or hybrids : 1 from Topred Delicious, 1 from Erovan, 1 from Querina (a scab resistant variety) and 2 from a selection originating from a second generation of selfing Golden Delicious. The haploid raised from Topred Delicious was doubled by in vitro culture; it is the first homozygous apple clone.

We try to get other haploids from different varieties and advanced scab resistant selections. We use the same technique combined with delayed pollination and pollen irradiation.

\title{
1. Introduction
}

In the cultivated apple, experiments were carried out to screen for haploid seedlings. In a first attempt, one apple haploid seedling originating from the cultivar Topred Delicious has been selected by using a seedling marker as male parent (Lespinasse et Godicheau, 1980). Four new other apple haploids have been selected from different varieties or hybrids by using the same technique. 
2. Potential value of haploidy in genetic studies and breeding of apple

\subsection{Cytological studies}

The basic chromosome number ( $\mathrm{x}$ ) of apple is 17. Several authors have tried to explain the origin of this number. Darlington et Moffett (1930) postulated that the tribe Pomoideae originated from a diploid species with $x=7$ by doubling of the entire set, plus the addition of 3 chromosomes of the original 7 bivalents $(7+7+3=17)$. This hypothesis was supported by the chromosome number $(x=7)$ in many genera in the family Rosaceae, particularly within the tribe Rosoideae. Sax (1931) found it much more probable that 8 was the original basic number and that Malus is tetraploid plus one bivalent. According to these hypotheses, the Pomoideae are complex autopolyploids. Their conclusions were supported by the tendency for the chromosomes to associate in groups (secondary pairing) at meiosis. Later, Sax $(1932,1933)$ modified his views and postulated that the Pomoideae are allopolyploids, produced by hybridization between different primitive forms in the Rosaceae, followed by chromosome doubling. Stebbins (1950), on morphological grounds, postulated that the Pomoideae are amphidiploids between primitive members of the tribes Spiraeoideae and Prunoideae $(9+8=17)$.

In haploids, pairing affinities, if any, between non-homologous chromosomes, which are impossible to detect in the diploid, may be revealed at meiosis. Thus, the study of chromosome pairing in the apple haploids will be important as a measure of the level of chromosome duplication within the genus. Such information may be of value in understanding the origin of the Pomoideae, at least to tell whether the Pomoideae are of autopolyploid or allopolyploid origin.

Nevertheless, the results obtained by studying the pairing relationships in haploids derived from polyploid species with regard to chromosome homologies have often been very inconclusive as pointed out by Kimber et Riley (1963). Application of Giemsa staining procedure that permits the distinction of much greater morphological detail in the chromosomes should allow more precise conclusions.

Using the Giemsa procedure or by classical karyotype determination, it may be possible in a haploid to make a draft karyotype of the apple chromosomes. Each homologue is represented only once and the task of matching homologues in karyotype analysis is eliminated.

This is very important in apple which has very small chromosomes which are difficult to stain (Lespinasse \& Salesses, 1973).

\subsection{Genetic studies}

Mutagenesis is a very suitable method to improve a species such as apple, usually multiplied vegetatively. Many mutants have been selected following irradiation with gamma rays from cobalt 60 source (Decourtye et Lantin, 1971). Obviously, irradiation of haploid plants would enlarge the range of mutants. All induced mutations, whether recessive or dominant, would appear immediatly and can be stabilized after chromosome doubling in a completely homozygous genetic background. 
This would be very useful for fondamental research, and where mutations occurred in layer II, which produces gametic tissues, the heritability of mendelian traits could be studied.

Moreover, homozygous clones may serve as standards when evaluating unknown genotypes for various measurable characters. They are very suitable for estimates of variance due to environment or to genotype-environment interactions.

\subsection{Apple breeding}

After doubling the number of chromosomes, the plants obtained will be the first completely homozygous apple clones. Producing totally homozygous clones is only feasible by using the haploid method. Apple selfing is difficult, some varieties are completely self-sterile, others are to some slight extent self-fertile but reveal strong inbreeding depression.

Homozygous apple clones, if fertile, should be valuable tools for the breeder, serving as parents which can transmit desirable genes to each gamete. True homozygous clones may be very valuable for creating Fl lines for rootstock purpose. These Fl lines could express a heterotic effect but would be perfectly homogeneous. Development of a good semi-vigorous rootstock remains an important objective for propagating spur-type varieties, which are naturally precocious in fruiting and need good growth to renew the spur-bearing branches. Haploids might be sought among the species or advanced selections resistant to the main rootstock diseases and pests (Cummins et al., 1979), selecting resistant homozygous clones to be used in creating resistant F1 lines.

In scion variety breeding it would be interesting to look for haploids in the best varieties or among the scab-resistant varieties that carry the Vf or Vr gene (Lespinasse et al., 1979 ; Aldwinckle et Lamb, 1979). Advanced selections homozygous at the Vf locus (as determined by progeny tests), would produce haploids which were all resistant.

\section{Method of producing apple haploids and results}

\subsection{Material and methods}

The diploid cultivars from which haploid seedlings were desired were pollinated with a hybrid derived from Malus pumila niedzwetzkyana. This hybrid is homozygous for a dominant marker gene, R, which determines the anthocyanin color of leaves, stem, flowers, and fruit.

Controlled crosses were made in muslin-covered cages, enclosing entire trees. Pollination was done by hand or by using bees with the pollinator (red phenotype) inside the cage. Theoratically, all the seedlings are red because of dominance of red over green, but some green seedlings appeared. The green phenotype seedlings, presumably of a maternal origin, were selected as early as 3 weeks after germination from the resultant progenies.

The chromosomes of these green phenotype seedlings were counted using a technique developed by Lespinasse et Salesses (1973). 


\subsection{Results}

\subsubsection{Pollination by using bees}

In the first attempts, in 1976 and 1977, we used only the bees for pollination in order to try to get a maximum of seeds (table 1). In all, 635 green phenotype seedlings were selected from 9969 seedlings raised from 4 different crosses involving spur-type Golden Delicious, Wellspur Delicious, Redspur Delicious and Topred Delicious (Lespinasse et Godicheau, 1980). Among these 635 green phenotype seedlings, only one haploid was identified by chromosome counting using root tips. All the studied cells have 17 chromosomes. This haploid seedling originated from the diploid cultivar, Topred Delicious. Morphologically it is very distinct : a slender stem and narrow, thin leaves. Its growth was weak and it survived 4 years on its own roots. After grafting on diploid apple seedlings, the haploid's growth is much more vigorous, which implies that the root system is very weak. At present, we have about twenty young trees of this haploid clone used for various experiments.

In 1982, using again bees for pollination and with the cultivars, standard Golden Delicious, Erovan, Gala and a scab resistant derivative from Antonowka, P7R4-4, we got the same results approximatively : a rather high percentage of green seedlings (6.6 compared to 6.4 in the previous experiments) but no haploid (table 2).

\subsubsection{Pollination by hand}

Pollination by hand performed better : we got in 1982, 4 new apple haploids and a very low percentage of green seedlings (0.3). One haploid originates from Erovan, one from Querina (a scab resistant variety carrying the Vf gene) and two from a selection (P21R4-30) originating from a second generation of selfing Golden Delicious (Table 3). The phenotype of these other haploid plants is very similar : a slender stem and narrow, thin leaves.

\subsection{Discussion}

- It is possible to get haploids and they originate from an unfertilized egg-cell (haploid parthenogenesis).

- The occurrence of haploid seedlings depends of the variety. We got two haploids from Delicious (Erovan and Topred derived by mutation from Delicious) ; no haploid was found with the variety Liberty despite a high number of seedlings examined : 4000 .

- With Querina, Erovan, P21R4-30 (pollination by hand) and Topred (pollination with the bees), we got roughly 1 haploid out of 1000 seedlings.

- With the bees, we got a higher percentage of green seedlings compared to pollination by hand. This year, we did a comparison with a same variety between pollination by hand and with the bees to try to elucidate the "bee effect". 
- We are also studying the origin of the green seedlings. In the first experiments (1976 and 1977) after chromosome counting, we mainly found diploid seedlings b ut some of them were triploid (Lespinasse et Godicheau, 1980). Several hypothesis have to be investigated to understand the origin of the green diploid and triploid seedlings : diploid parthenogenesis (after first division restitution - FDR - or second division restitution - SDR), selfing, misfunctionning of the marker gene.

\section{In vitro chromosome doubling}

\subsection{Material and methods}

Experiments were undertaken only with the haploid plant derived from the variety Topred Delicious.

Tips, about $2 \mathrm{~cm}$ in length, were excised from actively growing shoots and surface-sterilized, after leaf removal, in a solution of sodium hypochlorite (10\% Domestos) for 40 min., and then were rinsed in sterile distilled water.

Shoot proliferation was experimented on Murashige and Skoog salt mixture (MS) supplemented with $0.5 \mathrm{mg} / \mathrm{l}$ indolebutyric acid (IBA), $1 \mathrm{mg} / \mathrm{l}$ cytokinin BA (6-benzylamino purine), $0.5 \mathrm{mg} / \mathrm{l}$ GA3. The medium contained $30 \mathrm{mg} / \mathrm{l}$ sucrose and various vitamins; $\mathrm{pH}$ was adjusted to 5.3-5.5 before autoclaving.

For chromosome doubling, colchicine at $0.2 \%$ was used by applying droplets on the apex. Two applications were performed with an interval of 10 days.

\subsection{Results}

Shoot proliferation failed completely and a lot of shoot tips died. So, we decided to apply colchicine as indicated before on 2 surviving explants. No growth was observed and one month later, the shoot tips were transferred on shoot proliferation medium with a higher concentration of BA $(5 \mathrm{mg} / \mathrm{l})$. Shoot proliferation begun to start and we got enough explants to try rooting experiments.

Rooting was achieved by transferring individual shoots to half-strength MS medium supplemented with $0.5 \mathrm{mg} / 1 \mathrm{IBA}$ and $162 \mathrm{mg} / 1$ phloroglucinol (Jones, 1976). The medium contained $15 \mathrm{mg} / \mathrm{l}$ sucrose and various vitamins.

After rooting, plantlets were successfully transferred to pots.

Chromosomes were counted on root tips and shoot meristems; all the cells studied presented $2 n=2 x=34$ chromosomes.

\subsection{Discussion}

Chromosome doubling was only successful by in vitro culture. Different experiments realised in vivo in the greenhouse with colchicine gave no result. 
The studies concerning the in vitro culture of the haploid plants are in progress; we need such in vitro material to undertake caryotype analysis on the root tips and mutagenesis. Up to now, we never got any rooting of the haploid.

At present, we have 20 plants of this homozygous apple clone derived from Topred Delicious. Surprisingly, the growth of the doubled haploid plants is good to very good. After six months growth, the number of nodes of the highest plant is 78 ; we hope to get flowers in a few months. Figure 1 shows the leaf size of haploid, doubled haploid and parental clone.

\section{Conclusion}

These results raise new possibilities to improve our knowledge about genetic studies and apple breeding, but more haploids must be generated to demonstrate the breeding value of apple haploids. At Angers, we try to get other haploids from different varieties and advanced scab resistant selections. We use the same technique combined with delayed pollination and pollen irradiation ; about 50000 seeds will be screened next year. Hopefully, we will find 10 other haploid plants. To get more haploids may eventually be achieved through anther culture. Milewska-Pawliczuk et Kubicki (1977) failed to do so, but recently two papers from China claimed success : Wu Jiangyun (1981) obtained haploid plantlets of crab apples and Fei Kai-wei et al. (1981) got a haploid plantlet from the variety Delicious. These recent findings are promising and we may expect progress and interesting results in the coming years.

\section{References}

Aldwinckle, H.S., \& Lamb, R.C., 1979. Use of host plant resistance in tree fruits. IX International Congress of Plant Protection. Washington, D.C. 5-11 August 1979.

Cummins, J.N., Aldwinckle H.S. \& Forsline, P.L., 1979. Progress in breeding apple rootstocks. In : INRA Angers (Ed). : Proc. Eucarpia Fruit Section. pp. 251-261.

Darlington, C.D. \& MOFFETT, A.A., 1930. Primary and secondary chromosome balance in Pyrus. J. Genet. 22: 129-151.

Decourtye, L. \& Lantin, B., 1971. Considérations méthodologiques sur l'isolement de mutants provoqués chez le pommier et le poirier. Ann. Amélior. Plantes 21: 29-44.

Fei Kai-wei \& Xue Guang-rong, 1981. Induction of haploid plantlets by anther culture in vitro in apple cv. Delicious. Hort. Sinica, 8 (t): 44 (abstract).

Jones, O.P., 1976. Effect of phloridzin and phloroglucinol on apple shoots. Nature, $262: 392-393$.

Kimber, G. \& Riley, R., 1963. Haploid Angiosperms. Bot. Rev. 29: 480-531.

Lespinasse, Y. \& Marie Godicheau, 1980. Création et description d'une plante haploide de pommier (Malus pumila Mill.). Ann. Amélior. Plantes 30: 39-44.

Lespinasse, Y., Olivier, J.M. \& Marie Godicheau, 1979. Etudes entreprises dans le cadre de la résistance à la tavelure du pommier. In : INRA Angers (Ed). : Proc. Eucarpia Fruit Section. pp. 97-110.

Lespinasse, Y. \& Salesses, G., 1973. Application de techniques nouvelles à l'observation des chromosomes chez les genres Malus et Pyrus. Ann. Amélior. Plantes. 23: 381-386. 
Milewska-Pawliczuk, B. \& Kubicki, 1977. Induction of androgenesis in vitro in Malus domestica. Acta Hort. 78: 271-278.

Sax, K., 1931. The origin and relationships of the Pomoideae. J. Arnold Arboretum. 12: 3-22.

Sax, K., 1932. Chromosome relationships in the Pomoideae. J. Arnold Arboretum. 13: 363-367.

Sax, K., 1933. The origin of the Pomoideae. Proc. Amer. Soc. Hort. Sci. 30: $147-150$.

Stebbins, G.L., 1950. Variation and evolution in plants. Columbia Univ. Press, New York. p.361.

Wu Jiangyun, 1981. Obtaining haploid plantlets of crab apple from anther culture in vitro. Acta Hort. Sinica. 8 (4): 36 (abstract).

Table 1 - Occurrence of green and haploid seedlings in the progenies studied in 1976 and 1977.

Pollination with bees.

Marker $(R R)=F_{2}$ hybrid from M.p. niedzwetzkyana ( $\left.R r\right)$.

\begin{tabular}{|c|c|c|c|c|c|}
\hline \multirow{2}{*}{ Progenies } & \multicolumn{5}{|c|}{ Number_of seedlings and percentage } \\
\hline & germinated & green & $\%$ & haploid & $\%$ \\
\hline 1976 & & & & & \\
\hline Spur Golden X marker & 4552 & 116 & 2.5 & 0 & - \\
\hline 1977 & & & & & \\
\hline We11spur X marker & 2478 & 262 & 10.6 & 0 & - \\
\hline Redspur X marker & 1696 & 135 & 8.0 & 0 & - \\
\hline Topred $\quad \mathrm{X}$ marker & 1243 & 122 & 9.8 & 1 & 0.1 \\
\hline
\end{tabular}

Table 2 - Occurrence of green and haploid seedlings in the progenies studied in 1982 .

Pollination with bees.

\begin{tabular}{|c|c|c|c|c|c|}
\hline \multirow[t]{2}{*}{ Progenies } & \multicolumn{5}{|c|}{ Number of seedlings and percentage } \\
\hline & germina & greeen & $\%$ & haaloi므. & $\%$ \\
\hline Erovan $\mathrm{X}$ marker & 385 & 19 & 4.9 & 0 & - \\
\hline Standard Golden X marker & 1041 & 6 & 0.6 & 0 & - \\
\hline P7R4-4 X marker & 1182 & 130 & 11.0 & 0 & - \\
\hline Gala X marker & 719 & 65 & 9.0 & 0 & - \\
\hline
\end{tabular}


Table 3 - Occurrence of green and haploid seedlings in the progenies studied in 1982

Pollination by hand

\begin{tabular}{|c|c|c|c|c|c|}
\hline \multirow{2}{*}{ Progenies } & \multicolumn{5}{|c|}{ Number of seedlings and percentage } \\
\hline & germinated & _-_green & \% & haploloid & \% \\
\hline Querina (Vf/vf) $\mathrm{X}$ marker & 1001 & 3 & 0.3 & 1 & 0.1 \\
\hline Erovan $\mathrm{X}$ marker & 1120 & 2 & 0.2 & 1 & 0.1 \\
\hline P21R4-30 X marker & 2120 & 3 & 0.1 & 2 & 0.1 \\
\hline Prima (Vf/vf) X marker & 1519 & 1 & 0.1 & 0 & - \\
\hline Standard Golden X marker & 103 & 1 & 1.0 & 0 & - \\
\hline Liberty (Vf/vf) X marker & 4098 & 20 & 0.5 & 0 & - \\
\hline
\end{tabular}

Figure 1 - Leaf size of haploid, doubled haploid and parental clone Topred Delicious (drawn to a scale of $1 / 2$ )

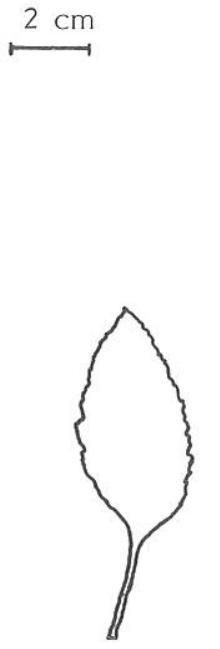

hap1oid

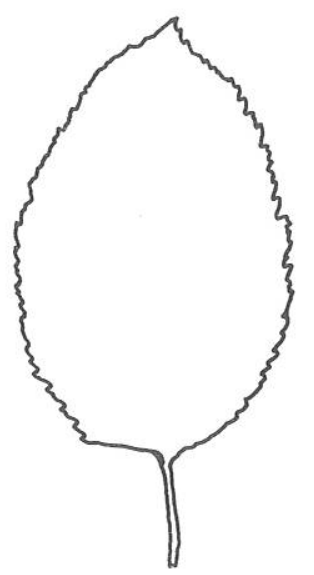

doubled haploid

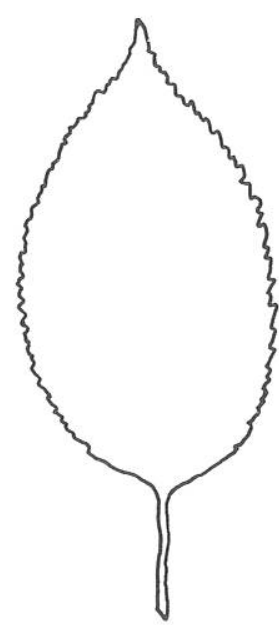

Topred Delicious (parental clone) 